\section{Kasım Karataş ${ }^{1}$}

Department of Education Sciences

Karamanoglu Mehmetbey University, Karaman, Turkey

Nadide Yilmaz ${ }^{2}$

Department of Mathematics and Science Education Karamanoglu Mehmetbey University

Karaman, Turkey
Original scientific paper

UDC: 37.022

DOI: $10.5937 /$ IstrPed2102377K

\title{
EVALUATING PROSPECTIVE MATHEMATICS TEACHERS' DEVELOPMENT OF ETHICAL KNOWLEDGE AND AWARENESS
}

\begin{abstract}
This study examines prospective mathematics teachers' ethical knowledge and awareness development in an undergraduate course called 'Morality and Ethics in Education'. Accordingly, prospective teachers' opinions regarding the ethical teacher and the unethical teacher were investigated through metaphors. The current study was designed as a case study and the data were collected from fifty-one prospective mathematics teachers studying at a university in Turkey through an open-ended questionnaire and reflective diaries. The findings show that the prospective teachers were satisfied with the 'Morality and Ethics in Education' course in general. It was effective and helpful to improve prospective teachers' ethical knowledge and awareness. In addition, the prospective teachers showed an interest in ethical values, such as justice, being a good role model and honesty. They describe the ethical teacher as being 'of holy personality, a guide and professional', and the unethical teacher as 'useless and harmful'. In addition, the prospective teachers made a number of suggestions for undergraduate education in the context of improving ethical and moral values.
\end{abstract}

Keywords: ethical, morality, prospective mathematics teachers, case study.

\section{Introduction}

Ethics is an important issue in every part of human life. This becomes clear and imperative as soon as its impact is felt in both daily and professional life (Chiodo \& Bursill-Hall, 2019; Ehrich, Kimber, Millwater, \& Cranston, 2011). It is a fact that any behavior not complying with ethical values will cause various problems (Karatas, Caner, Kahyaoglu \& Kahya, 2019). Professional ethics are expressed as common norms that guide professional staff in the process of conducting various professions and support the resolution of difficulties in performing the profession (Barrett, Casey, Visser \& Headley, 2012).

The role of educational sciences in the process of changing human behavior reveals the need to consider the concept of ethics. In this sense, the main goal in education is to change the behavior of individuals in a desired way. This behavioral change process should be in line with certain ethical principles (Aydin, 2016; Seghedin 2014). One important element of this process is teachers (Malone, 2020). The ethics of the teaching profession include the personal characteristics that a teacher should have, as well as the values, qualities and virtues that guide their practice (Tirri, Toom \& Husu,

\footnotetext{
1kasimkaratas@outlook.com / kasimkaratas@kmu.edu.tr

2nadideylmz70@gmail.com
} 
2013). These ethical values not only guide teachers, but also enable them to perform their professions in a professional way (Banks, 2003; Maxwell, 2017).

One branch of teaching where ethical rules must be considered is mathematics teaching (Boylan, 2016; Chiodo \& Bursill-Hall, 2019; Ernest, 2019). The questions such as, 'How do ethics concern the math teachers?', and 'What is ethical mathematics teaching?' are questions that researchers try to answer (Ernest, 2019). According to Ernest (2019), mathematics teachers have three ethical responsibilities. The first of these is related to their environment, and the second is related to their professional institutions. Their third responsibility is ethical responsibilities, arising from the teaching process as mathematics teachers. Researchers emphasize that mathematics educators generally ignore the ethical dimension of the subjects they focus on, but mathematics and ethics are intertwined by the nature of mathematics (Warnick \& Stemhagen 2007). However, the components related to complying with the ethical rules in mathematics education constitute the unique aspect of discussing ethics and education in terms of the mathematics teacher (Ernest, 2019).

The necessary knowledge and skills related to the ethical responsibility of mathematics teachers are the responsibility of undergraduate education programs, as well as in-service training programs, as in other teaching fields (Malone, 2020). The direct impact of the prospective mathematics teachers' perspective on ethics in their teaching profession and teaching processes makes undergraduate education even more important (Alcock, Hernandez-Martinez, Patel \& Sirl, 2020; Richardson, 1996). In addition, the changing duties and responsibilities of the teachers create the need to update teacher-training programs, and it is emphasized that the necessary knowledge and skills regarding teacher professional ethics should be included more often in teacher training programs (Kumar \& Singh, 2010). In the same way, a number of researchers draw attention to the contribution of prospective teachers' professional development of reasoning, in terms of ethical problems, during their training as teachers (Mergler, 2008). The institutions that structure the teaching profession also highlight that the teachers should have ethical principles and explain one of the characteristics that prospective teachers should have as 'adopting professional ethics' (The Council of Higher Education 2007; National Association for the Education of Young Children [NAEYC] 2005; National Association of State Directors of Teacher Education and Certification [NAS-DTEC] 2015; National Education Association [NEA] 2015).

The increasing importance related to what ethics is and how it should be implemented in the teaching profession has led to the need for more work in this field. Both politicians involved in education and researchers emphasize the need to establish ethical values regarding the teaching profession. In Turkey, one of the recommendations taken at the 19th National Education Council is expressed as, 'As in every profession, the ethical codes and professional standards of the teaching profession, which are strategically important in increasing the social reputation of the teaching profession, should be established immediately and shared with the relevant parties.' (MoNE 2017). Both this decision and the points emphasized by the researchers draw attention to the need to create ethical values regarding the teaching profession (Barrett et al., 2012; Maloney \& Matthews, 2020; Weil 2005). Teachers follow the teaching of professional ethical principles and standards, including justice, equity, providing a healthy and safe environment, avoiding corruption, honesty, righteousness, neutrality, occupational commitment, continuous improvement, respect, and effective use of resources (Aydin, 2016). It is thought that presenting such ethical values will support teachers and teacher candidates to make consistent, transparent and rational decisions (GelmezBurakgazi \& Can 2018). In addition to this, although there are certain common ethical values in the teaching profession, it is important to determine ethical values specific to mathematics teaching and to reveal these values (Boylan, 2016; Ernest, 2019). As in all other teaching branches, mathematics teachers, being role models for their students, means that they affect the development of students in every respect. Researchers also emphasize that ethics should be explicitly addressed in mathematics (Atweh, 2013; Atweh \& Brady, 2009; Ernest, 2012, 2019; Neyland, 
2004; Roth, 2013; Warnick \& Stemhagen, 2007). It is noteworthy that studies focusing on ethics in mathematics education emphasize different points. Studies explain the ways in which mathematics teachers distinguish ethical approaches as utilitarian and deontological (Atweh, 2014), and emphasize co-decision in the structuring of ethical rules (Atweh \& Brady, 2009; Neyland, 2004). Ernest (2012) state that while developing ethical values in mathematics, the social and cultural context cannot be ignored, and they cannot be considered independent from the global situation. Roth (2013), on the other hand, emphasizes the importance of developing dialogue and dialogue relations in order to examine pedagogical situations in more detail, in terms of ethics in the process of mathematics teaching. In addition, the common point of researchers is that individuals who will teach mathematics should be aware of the necessary knowledge and skills related to ethics (Ernest, 2019). Based on these studies, there are two main reasons to determine the opinions of future mathematics teachers with regard to being an ethical teacher. In this way, prospective teachers will develop awareness and knowledge of ethical values. In addition, these values will be a guide for prospective teachers while performing their work in the future. In this context, the development of ethical knowledge and awareness of prospective secondary school mathematics teachers during their undergraduate education and graduating having adopted ethical teacher values are evaluated as important qualities.

This study aims to evaluate how the theoretical explanations and in-class, out-class practices conducted within the scope of the 'Morality and Ethics in Education' course during the undergraduate education contributes to the development of the ethical knowledge and emotions of prospective mathematics teachers. We also examine their thoughts regarding ethical teachers through metaphors. Moreover, we gather their opinions on how to raise a mathematics teacher who is sensitive to moral and ethical values. With this research, we aim to draw attention to the need for prospective mathematics teachers to be equipped with ethical values. We also think that these research findings will contribute to the formation of professional ethical values related to mathematics teaching. From this point of view, the research questions in this study are as follows:

a) What are the ethical values that a mathematics teacher should have according to prospective mathematics teachers?

b) What are the characteristics of the ethical and unethical teacher?

c) What are their views on the effectiveness of the 'Morality and Ethics in Education' course?

d) What are their suggestions for raising a mathematics teacher sensitive to ethical values?

\section{Method}

\section{Research Design}

We chose a case study from qualitative research patterns in order to evaluate the development of the ethical knowledge and feelings of prospective mathematics teachers based on different data sources. The case study is a research pattern that provides the researcher with rich detailed data and enables the answering of questions as to 'how' and 'why', which are specific to a case (Yin, 2017). In addition, assessment focused case studies, which are among the categories of case study, allows for the uncovering of value judgments regarding education programs, systems and projects (Bassey, 1999). Patton (2014) states that case studies are valuable research concerned with creating meaning in a wide range of ways regarding certain individuals, problems and situations. In addition, the holistic single case study, which is a case study type, is used in cases where there is a single analysis unit and a single case (Yin, 2017). One important feature of the case study is the limitation of the situation to be studied (Merriam, 2015). In this context, it is important to gather detailed information about the case in a limited context. Since this study aims to evaluate the development of prospective teachers' knowledge and awareness regarding ethics and morality, we use a holistic single-case study design. In other words, the analysis unit is the prospective mathematics teachers in 
this research, and the case is evaluation of the knowledge and awareness developments of prospective teachers on the 'Morality and Ethics in Education' course.

\section{The participants and research context}

We conducted this research at a university located in the Central Anatolia region of Turkey. In Turkey, there are 203 universities, and this university is ranked 104 in terms of academic performance (University Ranking by Academic Performance [URAP], 2019). The Faculty of Education of the University was established in 2011 and has five undergraduate programs. One of these undergraduate programs is the Elementary Mathematics Teaching [EMT] program. The participants of this research were 51 EMT candidates, 43 females and 8 males, in the 2019-2020 academic year. The ages of the prospective teachers varied between $19-26$ years.

In Turkey, undergraduate programs were updated in 2018 and the 'Morals and Ethics in Education' course was included as a compulsory subject in the EMT degree program (The Council of Higher Education 2018). This course takes place in the fifth semester of the EMT program. One semester lasts fourteen weeks, and this course is conducted face-to-face with prospective teachers in the form of two lesson hours per week. The general aim of the course is to create knowledge and awareness among prospective teachers, so that they can behave morally and ethically. The topics of the course are as follws: basic concepts and theories about morality and ethics; ethical principles, ethical rules, business and professional morality/ethics; the teaching profession with its social, cultural, moral and ethical aspects; ethical principles in education, training, learning and the evaluation process; ethical principles in relationships with education stakeholders; unethical behavior, ethical dilemmas, problems and solutions in schools and education; and moral/ethical education and ethical committees in schools.

\section{Course process and applications}

In the first four weeks of the course, the instructor (the first author) made theoretical presentations regarding ethics and morality. In the following ten weeks, under his co-ordination and supervision, the prospective teachers made practice related to the course in the classroom. First, the prospective teachers were divided into groups of four to six. Two topics were assigned to each group of prospective teachers regarding the 'ethical values that teachers should exhibit in their professional lives'. While creating these ethical values topic list, the related literature and the objectives of the 'Morality and Ethics in Education course were used. The list of topics is shown in the table below:

Table 1. Ethical values topic list

\begin{tabular}{llcl}
\hline 1 & Professionalism & 11 & Not discriminating among students \\
\hline 2 & Being a good role model & 12 & Not requesting donations and help \\
\hline 3 & Understanding and tolerance & 13 & No bribery/Corruption \\
\hline 4 & Being fair and equal & 14 & Not making psychological mobbing \\
\hline 5 & Honesty and accuracy & 15 & No physical, emotional or sexual abuse \\
\hline 6 & Being responsible & 16 & Not showing Violence-Pressure- Aggression \\
\hline 7 & Considering individual differences & 17 & Not to misuse duties and powers \\
\hline 8 & Resisting illegal orders & 18 & Not gossiping \\
\hline 9 & Not reflecting a negative psychological mood & 19 & Not flattering seniors \\
\hline 10 & Using school/state resources effectively & 20 & Not wasting working hours \\
\hline
\end{tabular}


Each topic was covered in one lesson hour. The prospective teachers were encouraged to use different methods and techniques while presenting the subjects during lessons. The various practices of the prospective teacher groups during the semester were as follows:

- $\quad$ Presenting slides

- Collaborative teaching techniques

- Making short films and showing them to other prospective teachers in the classroom

- Conducting interviews with experts and videotaping the interviews and having other prospective teachers watch and discuss them in the classroom

- Allowing other prospective teachers to watch and discuss the videos on the subjects through social media platforms.

At the end of each application, we conducted a question and answer activity in the classroom on the subject. Care was taken to prepare a suitable environment for the prospective teachers to present their opinions and to create a platform for discussion. In addition, at the end of each lesson, the other prospective teachers scored the group that had presented in the lesson in terms of processing performance. These scores were assessed as their midterm grade. At the end of the term, the participants were asked to make a self-assessment in terms of gaining awareness of ethical behavior and exhibiting behavior in accordance with professional ethical rules in the future. The aim was to get the prospective teachers to rate themselves, with the results becoming their final scores.

\section{Data collection tools and data collection processes}

In studies designed as case studies, data collection can generally be comprehensive, and more than one data collection tools can be conducted. Indeed, providing an in-depth understanding of a situation is the distinctive feature of a qualitative case study. To achieve this, the researcher should collect information from many data sources. It is stated that data obtained from a single source will be insufficient to reveal in-depth understanding (Creswell \& Creswell, 2017). For this purpose, we used various data sources, as we wanted to make an inclusive perspective on the development of ethical knowledge and awareness. In this context, we obtained the data with the help of openended questionnaires and reflective diaries

Open-ended questionnaire: An open-ended questionnaire is a data collection tool in which participants express their opinions in writing (Creswell \& Creswell, 2017). We used a questionnaire, consisting of open-ended questions, in order to learn the opinions of prospective teachers on ethical knowledge and awareness development. The open-ended questionnaire consisted of two parts. In the first part, the prospective teachers evaluated the effectiveness of the course they had taken during the semester, the course implementation style, the effectiveness of the diaries they had written every week, and the efforts of the lecturer to be a role model in terms of ethics and morality out of ten points. In the second part, there were questions related to the prospective teachers' development of ethical knowledge and awareness, their opinions on ethical teachers and their suggestions on what should be done to train teachers who are sensitive to ethical values.

Reflective Diary: During the semester, each prospective teacher was asked to write reflective diaries on the ethical issues covered in the lessons. It is stated that keeping a reflective diary is beneficial to prospective teachers in a number of ways, such as obtaining permanent information, putting what they know into practice, organizing their thoughts, and learning what they know and do not know about the subject (Cengiz, 2014). In this sense, the aim was to get the prospective teachers to write a diary in order to question their thoughts on ethical issues and to develop their self-awareness. The prospective teachers were expected to answer the following questions while writing their diaries: 'What did I learn today?'; 'What awareness did I gain?'; 'When I consider the lesson content today, what are my gains in terms of personal and professional development?'; and 'How do I judge myself 
when I become a teacher to abide by the ethical rules that are covered today?'. The diaries of the prospective teachers were accessed through the 'Google Classroom' application.

\section{Analysis of data}

We analyzed the data through an inductive approach with the help of content analysis. Qualitative data analysis is predominantly inductive in nature (Teddlie \& Tashakkori, 2003). On the other hand, while conducting inductive content analysis, line-by-line open coding was used to analyze each of the open-ended questions, which generated numerous meaning units documented in a coding manual. By applying constant comparative methods (Lincoln \& Guba, 1985), these meaning units were then compared across participants as the research team reduced the data. A deductive approach can be adopted for testing and validating the authenticity and appropriateness of inductive content analysis (Patton, 2014). In this sense, in the deductive content analysis, as the researchers reached consensus, the team collapsed and renamed coded meaning units until they collectively determined final shared themes. In addition, while analyzing data on certain themes and reporting the findings, quantification was used. On the other hand, while reporting the themes and sub-themes obtained from the open-ended questionnaires, direct quotations from the opinions of the prospective teachers were made. We also supported themes with data obtained from the reflective diaries. The names of the prospective teachers were not used when citing their opinions. Instead, codes such as EMT1, EMT2 and so on, were used. For the data obtained from the diaries of the prospective teachers, the initial letter of the prospective teacher's name and surname and the date of the diary entry was used as the code (Ex; AG (27.11.2019)). Finally, descriptive statistics when analyzing the data obtained from the first part of the open-ended questionnaire were included.

There are many strategies to increase the credibility, transferability and consistency of case studies (Creswell \& Creswell, 2017). First, data was collected from a sufficient number of participants in accordance with the data collection processes. After this, in order to overcome the limitations of a single data collection method and to interpret the findings from a holistic perspective, data triangulation was used. Triangulation is viewed as a qualitative research strategy to test validity through the convergence of information from different sources (Carter, Bryant-Lukosius, DiCenso, Blythe \& Neville, 2014). Data triangulation refers to the use of multiple methods in qualitative research to build a comprehensive understanding about a case (Patton, 2014). In order to increase the consistency of the research, we consulted peer review to examine and critically evaluate the processes from the research design to the data collection, the theme and the writing of the findings. In addition, we obtained participant confirmation on the theme and findings by contacting a number of the prospective teachers in order to avoid misunderstandings that may have arisen from subjective assumptions regarding the conclusions and interpretations of the research. While presenting and interpreting the findings, we formed a rich and intense description. Therefore, we made detailed explanations in order to increase the transferability of the research findings and to put the findings into a certain context. In addition, we shared the raw data with readers within the framework of certain themes by making direct quotations from the prospective teachers' views and diaries for transferability.

\section{Results}

\section{Theme 1: The metaphor of the 'Ethical teacher'}

We used metaphors to understand the opinions of the prospective teachers with regard to ethical teachers who have adopted ethical values and who take care to exhibit ethical values in their personal and professional lives. We see that the prospective teachers associate the ethical teacher with the metaphors 'holy personality', 'guide' and 'professional'. The prospective teachers' metaphors relating to 'the ethical teacher' are shown in Table 2. 
Table 2. Ethical teacher metaphors according to the prospective teachers

\begin{tabular}{llll}
\hline Metaphor & $f$ & Metaphor & $f$ \\
\hline Compass & 4 & Precision Balance & 1 \\
Tree & 3 & Caliph Umar & 2 \\
Mother-father & 3 & Door & 1 \\
Sun & 3 & Snowdrop & 1 \\
Prophet Muhammad & 3 & Butterfly & 1 \\
Candle & 3 & Egyptian Pyramids & 1 \\
Flower & 2 & Sultan & 1 \\
Book & 2 & Robot & 1 \\
Water & 2 & Hour & 1 \\
Rain & 2 & Queen in chess & 1 \\
Constitution & 1 & Eraser & 1 \\
Brain & 1 & Star & 1 \\
Sea & 1 & Alphabet & 1 \\
Electricity & 1 & Computer & 1 \\
\hline
\end{tabular}

At this point, the prospective teachers' views on the ethical teacher are presented by three main metaphors.

The ethical teacher is a guide.

According to the opinions some prospective teachers; a teacher who has adopted ethical values is a guide for students. Sample statements regarding the opinions of the prospective teachers are as follows:

EMT 52: "I would liken the ethical teacher to the sun because the ethical teacher is our source of life. He is the one who illuminates our day and our path at the end of darkness. With his compassion, love and helpfulness, the teacher gives warmth to his students just like the sun."

The ethical teacher is a holy person.

According to some prospective teachers, an ethical teacher prioritizes universal values. They advocate justice and equality. They continue to enlighten society even after they die by bestowing their good morals on humanity. Quotations from the opinions of some of the prospective teachers are as follows:

EMT 28: "The ethical teacher is like the Prophet Muhammad. As a teacher, he teaches both religion and humanity. Most importantly, while doing these things, he never breaks a person's heart, damages their dignity or lies. He gives duties and responsibilities according to individual differences. While exchanging ideas, he receives and respects everyone from the youngest to the oldest. He never judges people because of their religion, language, race or status."

The ethical teacher is a professional.

The prospective teachers think that the ethical teacher will work to provide students with knowledge by doing his job well and by sacrificing. Likewise, an ethical teacher is a person who is a specialist at his work, and can carry out an effective teaching process with his students while being a role model in every respect. Students understand that he will try to perform his job in the best way using different teaching methods and techniques.

EMT 16: "He is like the door to life and dreams. Everyone wants to reach that door and open it. The ethical teacher becomes a role model with his attitudes, messages, stance, and behavior, and aims to direct and support his students... This is because teaching is not only a profession within the boundaries of the school. 


\section{Theme 2: The metaphor of 'Unethical teacher'}

Within the scope of this theme, we tried to understand the opinions of the prospective teachers about unethical teachers who do not comply with ethical values in their personal and professional lives, by using metaphors. Considering the metaphors and explanations of the prospective teachers regarding unethical teachers, they generally evaluate unethical teachers as 'useless and inefficient' and 'harmful'. The metaphors relating to unethical teachers are shown in Table 3:

Table 3. Unethical teacher metaphors

\begin{tabular}{llll}
\hline Metaphor & $f$ & Metaphor & $f$ \\
\hline Fruitless tree & 3 & Dry land & 1 \\
Garbage & 3 & Cancer cell & 1 \\
Swamp & 2 & Piece of wood & 1 \\
Humid weather & 1 & Alcohol & 1 \\
Monkey & 1 & Ivy & 1 \\
Banana slicer & 1 & Disaster & 1 \\
Cockroach & 1 & Gravity & 1 \\
Cigarette & 1 & Desert & 1 \\
Snowball & 1 & King in chess & 1 \\
Garbage truck & 1 & Blacksmith & 1 \\
Thief & 1 & Parasite & 1 \\
Broken chair & 1 & Chameleon & 1 \\
Android phone & 1 & Unused library & 1 \\
Sea & 1 & Wall & 1 \\
Closed box & 1 & Wound & 1 \\
Ketchup & 1 & Wild animal & 1 \\
Heeled shoes & 1 & Pig & 1 \\
Earthquake & 1 & Broken clock & 1 \\
Cigarette & 1 & Gum & 1 \\
Mint candy & 1 & & 1 \\
\hline
\end{tabular}

At this point, the prospective teachers' opinions regarding the unethical teacher are presented in two main metaphors.

The unethical teacher as useless and inefficient.

The prospective teachers emphasize that unethical teachers would not benefit students, would not fulfill the requirements of their profession, and would cause students to exhibit undesirable and unethical behavior as a wrong role model. Sample statements from the opinions of some of the prospective teachers are presented below.

EMT24: "I liken the unethical teacher to dry land. He is inefficient like dry land. He cannot ensure the growth and development of his students. Just as there is no life in dry land, there are no good or moral individuals in the environment where there is an unethical teacher."

Unethical teacher giving harm.

The prospective teachers stated that an unethical teacher does not benefit the personal and academic development of their students; moreover, they can also harm their students. 
EMT9: "Actually, we can compare it to a snowball rolling down a mountain. This snowball will also grow and eventually turn into an avalanche causing enormous damage. Likewise, the unethical teacher will have created a huge avalanche by the end of his career with all the students he has taught and educated."

\section{Theme 3: Effectiveness of the 'Morality and Ethics in Education' course}

Within the scope of this theme, we discussed the opinions of the prospective teachers concerning the effectiveness of the 'Morality and Ethics in Education' course. We can see that the prospective teachers generally state that this lesson is effective. The prospective teachers state that the content and application methods of the course contribute to their personal development. In addition, they specify that this course contributes to the development of their empathetic skills and their ability to interpret events from different viewspoints.

EMT25: "I think my empathy skills have improved. Thanks to this lesson, I became more aware of my patience, limits, and myself. I have learned how ready I am for the profession or what I am missing in order to be ready and how to fill these deficiencies."

The prospective teachers, who expressed their opinions about the content of the course, stated the contribution of the course practice (slides, short films, videos, and interviews) carried out in the process as follows.

EMT51: "I would not think in such a way if the lecture had been conducted as a narrative technique. This is because the visual narration, the narration through videos, the videos we recorded, and the real-life stories enriched the lesson. This encouraged me to think and I expressed my thoughts on this subject in my diaries. Therefore, this lesson has contributed a lot to me."

The prospective teachers expressed how this lesson contributed to their learning with regard to values and the way they should comply in their professional teaching lives in the following way.

EMT16: "I better understood that the only duty of the teacher is not to teach and leave the classroom. Therefore, I think twice if I get into a wrong attitude in my normal life. I can say it improved my empathy skill more, such as how real is my performance, and how I would feel if it was done to me."

Findings from reflective diaries

The prospective teachers stated in their diaries that the ethical issues covered each week raised their personal and professional awareness and that the lessons are effective and efficient. Below are a few examples of the opinions of the prospective teachers; BE (27.11.2019): "Today, my group and I made our presentation. I think we made a good presentation. We also included our foreign friends in our lesson in the presentation. We enjoyed presenting it." KU (18.12. 2019): "I like the Morals and Ethics Course, it goes well. The course is not boring, as the subjects affect our teaching lives. This course gives good things for us in our future lives and we can provide for our students, other teachers, parents and other people in our lives. We can make good changes in them and affect their lives."

The prospective teachers shared sincere experiences concerning unethical events they had faced and encountered in the past, and criticized unethical situations. 
EY (27.11.2019): "They presented us with a more effective expression with the videos and interviews they recorded. As they explained, my past experiences passed before my eyes. The bad behavior of our teacher towards us.... It all crossed my mind like a filmstrip, it was very effective. I liked it very much."

The prospective teachers stated that a number of student groups could not organize ethical issues well and could not use effective methods and techniques.

KK (23.10.2019): "While the first group made its presentation, the participants asked questions to activate us and asked us to talk about the videos they had recorded. However, I see this as a deficiency as the group members interrupted each other and, in some cases, were indecisive during the presentation process."

The prospective teachers also state in their diaries that they would try to be an ethical role models when they become teachers in the future. They think that being an ethical role model is more effective than preaching ethical rules to students and asking them to obey them.

AG (27.11.2019): “... since students see teachers as role models, our behavior is so important that we can drag them to completely different lives by making small imprssions on the lives of students with a single word and action."

The prospective teachers, on the other hand, state that they face a of number unethical situations during their education period and sometimes they might act unethically themselves. They state that the reason for their unethical behavior is sometimes due to not knowing that the action is unethical. They express that they sometimes act unethically because it will be against their interests, so they behave unethically. In addition, they express the opinion that they will now behave in accordance with ethical and moral rules with the awareness that this course has created in them. Since the teacher candidates did not allow direct quotations about this situation, even though their names are hidden, quotations are not included here. The outstanding situations in the analysis of the diaries in general are shown in Figure 1.

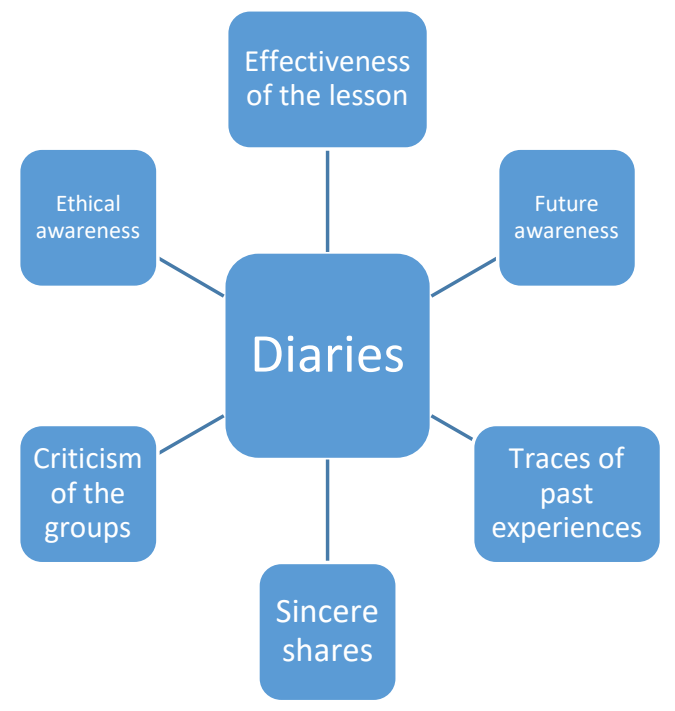

Figure 1. Outstanding situations in the analysis of the diaries 


\section{Theme 4: Suggestions for training teachers sensitive to moral and ethical values}

Within the scope of this theme, we discussed suggestions from the prospective teachers with regard to how to train a mathematics teacher who is sensitive to ethical and moral values. First, the prospective teachers emphasized the importance of this course in order to qualify as a teacher. They also said that they liked the application and process of the course and that it should continue to be conducted in this way:

EMT39: "This process was completely followed in the course of morality and ethics in the education I received this year. The applications were conducted. We have acted out individuals with ethical and unethical behavior. Its lasting effect was very high. It was also very efficient in creating awareness."

EMT47: "Our implementation of the course this year was actually good because these ethical values cannot solely be gained by reading books. I think we conducted it in the most efficient way."

On the other hand, the prospective teachers are of the opinion that it is not possible for a prospective mathematics teacher to acquire ethical values through one course alone, and that it should be extended to the entire undergraduate education process. They also stated that the ethical development of individuals depends on the family and the environment they grow up in as follows:

EMT5: "This values education should start in primary school, because when students enter the undergraduate program, they become people who already have established personalities, characters, and certain ideas, but this type of value education should be given throughout their education, starting from primary school, and even from the family."

The prospective teachers generally think that theoretical information regarding ethics and moral principles should be given during the undergraduate education process. In the same way, they defend the view that methods and techniques should be followed in order to gain experience in which they can be active both inside and outside the classroom:

EMT19: "It should be taught with a constructivist approach because ethical values can become more permanent with the participation of students in the course."

The prospective teachers consider that sharing should be made on sample ethical cases in the learning-teaching process. They also emphasize that they should be informed about how ethical behavior should be displayed, and how to raise awareness through sample ethical cases."

EMT13: "It can also focus on values that need to be developed. In addition, examining cases within the course supports them and adds realism and vitality to the subject."

EMT17: "While the teacher develops our ethical and moral values, he/she can make students realize something through thinking about these issues by starting from examples from daily life."

Another point suggested by the prospective teachers, in order to train teachers sensitive to moral and ethical values, is that senior teachers and prospective mathematics teachers should meet together. They emphasize the importance of sharing senior teachers' experience on how they cope with the ethical problems they encounter in their professional lives with prospective teachers. In addition, they suggest that prospective teachers attend seminars and conferences on morality and ethics. 
EMT35: "It is necessary that similar courses, such as morality and ethics in education, should be more common. Again, within the scope of this course, opportunities to participate in conferences and workshops should be offered, not only at school, but also outside."

Another point that the prospective teachers mention is that faculty members should comply with ethical and moral values and become role models for them.

EMT24: "First, the 'Morality and Ethics in Education' course must be included in the undergraduate program in order to ensure that prospective teachers become truly ethical and moral individuals. Of course, just being in the curriculum of the course is not enough to improve ethical and moral values. Faculty members on other courses should also be good role models for prospective teachers.

In general, the suggestions of the prospective teachers are presented by visualizing them in the following figure:

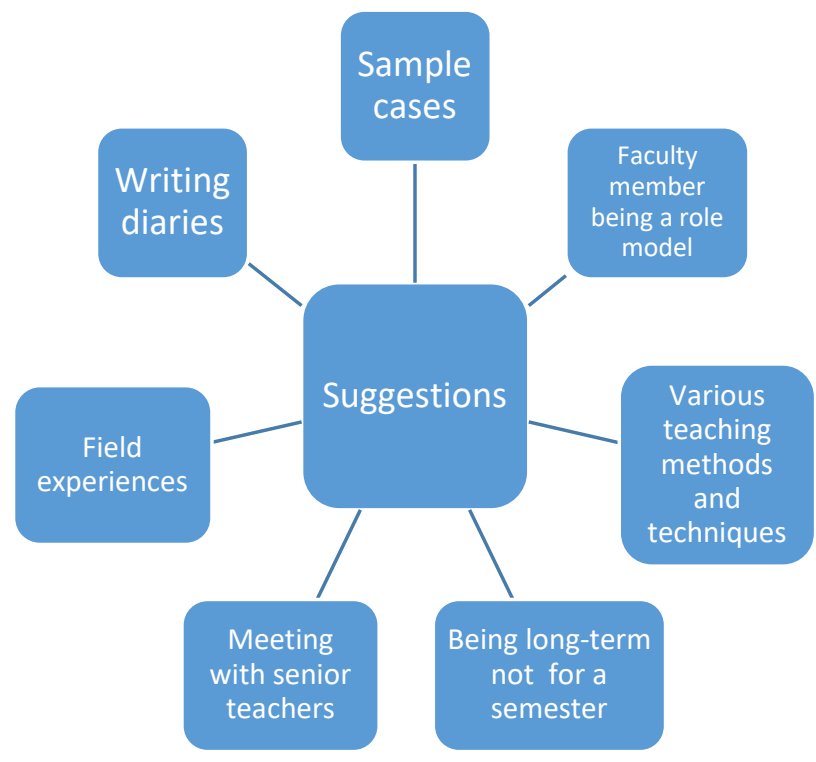

Figure 2. Suggestions for the development of prospective teachers' ethical values

In general, the prospective teachers attach importance to the ability of prospective mathematics teachers to behave in accordance with ethical values in their professional lives. They suggest that the undergraduate education process should be evaluated well in order for prospective mathematics teachers to develop their ethical and moral understanding and gain knowledge and awareness.

\section{Discussion and Conclusion}

In this study, we examine the development of ethical knowledge and awareness in the context of the 'Moral and Ethics in Education' course in the undergraduate program of prospective mathematics teachers. When we evaluate the findings in general, we can claim that the course is effective and it improves ethical knowledge and awareness of the prospective teachers according 
to their opinions. Behaving in accordance with ethical values is an indispensable obligation of a teacher, regardless of his/her branch. In this sense, it is necessary to enable an understanding of ethical values for prospective mathematics teachers during their undergraduate education and to make them aware of ethical values. In fact, it is emphasized that all prospective teachers should be educated with ethical values during undergraduate education (Maxwell et al., 2016). In addition, it is stated that teachers' behavior in accordance with ethical values will make the mathematics teaching and learning process more effective for both teachers and students (Ernest, 2019). In this study, prospective teachers consider ethical values as an important part of the teaching profession. In addition, it can be seen that they emphasize more ethical values, such as justice, being a good role model and honesty. This finding is consistent with different studies in the literature. Aydin (Aydin, Guner-Demir, Toptas \& Erdemli, 2020) emphasize that teachers should act in accordance with the ethical principles of justice and honesty in their professional lives. Ordu (2019) lists ethical values as role models, considering the individual differences of students and non-discrimination in his study. Tanswell and Rittberg (2020) state that mathematics teachers should avoid injustice, otherwise they violate ethics. In addition, they emphasize that in order for mathematics teachers to provide justice, they should provide mathematics education while considering their students' cultural or class backgrounds. In a study by Altinkurt and Yilmaz (2011), 'not paying enough attention to unsuccessful students' is considered as unethical behavior according to prospective teachers. Another finding of this study is that teachers who cannot adopt ethical behavior will not benefit their students' personal and academic development, and will be a bad role model for them. Education and ethics are two important components that complement each other. In this context, one of the biggest obstacles to effective and efficient education can be teachers committing ethical violations in the education process and not displaying an appropriate role for ethical behavior. Teachers, as good role models, affect students positively and vice versa (Coskun, 2016). In their study, Karatas and et al. (2019), found that prospective teachers consider qualified teachers, who are role models through their behavior, as ethical teachers. Maxwell (2017) emphasizes that a teacher should be a good model and should avoid attitudes and behavior that would constitute bad examples. At this point, role model teachers, who act in accordance with ethical rules, will not only contribute to the personal and academic development of their students, but also to the development of ethical awareness and values. In fact, according to Lilja (2017), teachers are in a position of natural-role models in the ethical and moral development of their students. In this context, more effort should be made to improve the ethical awareness of future teachers during the undergraduate education process.

Researchers mostly emphasize that ethics education is generally inadequate, and that it should be given importance for students in higher education (Bourke, Kinsella \& Prendeville 2019; Gulcan, 2015; Lundin, 2012; Sims \& Felton, 2005; Warnick \& Silverman, 2011). Similarly, researchers emphasize that prospective mathematics teachers should acquire the necessary knowledge and sensitivities regarding ethics (Aybek \& Aslan, 2017; Ernest, 2019). Sahin-Kiralp and Manolova-Yalcin (2017) stated that, apart from theoretical knowledge, different methods and techniques, such as case studies, should be used to help prospective teachers to internalize ethics. In fact, in another finding from this study, prospective teachers suggest that training on ethics should not be limited to a single course, but should be extended to the undergraduate education process by increasing their number. In addition, the prospective teachers consider that there should be real life practice of theoretical knowledge in these courses, and analysis should be conducted based on sample cases. Warnick and Silverman (2011) state that student teachers can benefit from a discussion-oriented, stand-alone course dedicated specifically to professional ethics for teachers. In addition, Sims and Felton (2005) suggest striving to achieve a balance between the active engagement of students with issues and a critical analysis of choices made in real-life situations, co-ordination of different disciplines through case studies, and invitation to consultants from outside to provide a broader view of the various organizational sectors. Strike and Soltis (2009) propose using elements of ethical 
theory, case analysis, and the NEA [National Education Association] code of ethics to develop an ethical knowledge base, deliberative abilities, and analytical skills.

The prospective mathematics teachers emphasize the importance of the faculty member who will conduct the course on ethics in the undergraduate education process being a role model in terms of ethical behavior. In a number of studies, the effects of lecturers on undergraduate students as role models are emphasized (Harfitt, 2018; Izadinia, 2012; Lunenberg, Korthagen \& Swennen, 2007; Timmerman, 2009). Lumpkin (2008) emphasizes the important influence of teachers on students' ethical and character development. Lumpkin states that 'teachers serve as role models with the attributes of honesty, respect for others, accepting and fulfilling responsibilities, playing fair, earning and returning trust, and living a moral life. They should model the importance of engaging in a lifelong quest to 'do the harder well', rather than 'the easier wrongly' (p.49). Skoe (2010) state that teachers are moral and ethicals models who contribute to the development of care in students. With the same sensitivity, it is necessary for teacher trainers to adopt and apply ethical values for the ethical awareness and development of prospective mathematics teachers. Aleccia (2011) states that modeling is still an essential component of good teaching, besides knowing intimately about academic content knowledge of a subject. In their study, Asif (Asif, Guangming, Haider, Colomer \& Kayani, 2020) emphasize that faculty members are effective in the moral and character development of prospective teachers and, in this respect, they should be role models for prospective teachers. According to Narinasamy and Logeswaran (2015), ethics and morality education should be an important component of the teacher training process, and faculty members should not forget that they are role models for prospective teachers, both pedagogically and ethically. If this is not the case, discourse-action contradiction will negatively affect prospective teachers' development of ethical awareness.

As a result, teachers from any branch are expected to adopt ethical values and to comply with ethical values throughout their professional lives. In this respect, it should be ensured that prospective teachers learn professional ethical principles while strengthening their pedagogical competence in the teacher training process. In this context, the course of 'Morals and Ethics in Education' contributes to the ethics and awareness development of prospective mathematics teachers. Academicians emphasize the importance of training on behavioral ethics for students (De Los Reyes, Kim \& Weaver, 2017). Simola (2019) states that people should receive education and gain awareness about 'behavioral ethics', so that they can make ethical decisions quickly when they are faced with ethical dilemmas. In this sense, emphasis should be given to ethical education, not only for the undergraduate mathematics teaching program, but also in all programs of higher education.

\section{Limitations and suggestions}

In this study, we have attempted to draw attention to the importance of gaining ethical knowledge and awareness for prospective mathematics teachers. In this context, we carried out an intensive data collection and data analysis process. However, as in every study, this research has certain limitations. Since this study is limited to one university, Karamanoglu Mehmetbey University in Turkey, further research is needed at other universities and countries, along with comparative studies between countries. The qualitative findings of the study cannot be generalized. However, although different data collection methods have been used in the research, the main methodological drawbacks are that the findings have been obtained based on the prospective teachers' self-reports. In this respect, the main limitation of this study is that objective judgments cannot be obtained clearly and subjective judgments cannot be controlled. In this regard, we recommend that researchers use quantitative methods to confirm qualitative findings. This research is a cross-sectional study over one semester. Longitudinal studies are needed in order to evaluate the development of prospective teachers' ethical knowledge and awareness. In addition, scales with psychometric features should be developed in order that teachers can self-assess their ethical 
awareness. Furthermore, the competency of faculty members at being ethical role models should be evaluated. It is recommended to increase the number of qualified scientific studies that draw attention to the importance of the ethical and moral education of prospective teachers, benefit educational practices and contribute to the stakeholders in education.

\section{References:}

Aleccia, V. (2011). Walking our talk: The imperative of teacher educator modeling. The Clearing House, 84, 87-90. https://doi.org/10.1080/00098655.2010.524951

Alcock, L., Hernandez-Martinez, P., Patel, A. G., \& Sirl, D. (2020). Study habits and attainment in undergraduate mathematics: A social network analysis. Journal for Research in Mathematics Education, 51(1), 26-49.https://doi.org/10.5951/jresematheduc-20200044.

Altinkurt, Y., \& Yilmaz, K. (2011). Prospective teachers' views about teachers' occupational unethical behaviours, Mehmet Akif Ersoy University Journal of Education Faculty, 22, 113-128.

Asif, T., Guangming, O., Haider, M. A., Colomer, J., \& Kayani, S. (2020). Moral education for sustainable development: Comparison of university teachers' perceptions in China and Pakistan. Sustainability, 12(7), 3014. https://doi.org/10.3390/su12073014

Atweh, B. (2013). Is the good a desire or an obligation? The possibility of ethics for mathematics education. Philosophy of Mathematics Education Journal, 27, 1-11.

Atweh, B. (2014). Mathematics education and democratic participation between the critical and the ethical: a socially response-able approach. In O. Skovsmose \& B. Greer (Eds.), Opening the cage: critique and politics of mathematics education (pp. 325-342). Sense Publishers.

Atweh, B., \& Brady, K. (2009). Socially response-able mathematics education: implications of an ethical approach. Eurasia Journal of Mathematics Science and Technology Education, 5(3), 267-276. https://doi.org/10.12973/ejmste/75278

Aybek, B. \& Aslan, S. (2017). The relationship between pedagogical formation training certificate program prospective teachers 'critical thinking attitudes and their perceptions on professional ethical principles. European Journal of Education Studies, 3(2), 227 - 237.

Aydin, I. (2016). Yonetsel mesleki ve orgutsel etik. Pegem: Akademi Publishing.

Aydin, I., Guner-Demir, T., Toptas, B. \& Erdemli, O. (2020). Teachers' struggle with gifts: gift culture at schools and associated ethical problems. Ethics \& Behavior, 1-15. https://doi.org/10.1080/10508422.2020.1765170

Banks, S. (2003). From oaths to rulebooks: A critical examination of codes of ethics for the social professions. European Journal of Social Work, 6(2), 133-144. https://doi.org/10.1080/1369145032000144403.

Barrett, D. E., Casey, J. E., Visser, R. D., \& Headley, K. N. (2012). How do teachers makejudgments about ethical and unethical behaviors? Toward the development of a code of conduct for teachers. Teaching and Teacher Education, 28(6), 890-898. https://doi.org/10.1016/j.tate.2012.04.003.

Bassey, M. (1999). Case study research in educational settings. Buchingham, Philadelphia: Open University Press.

Bourke, M., Kinsella, W.J., \& Prendeville, P. (2019). The Implementation of an Ethical Education Curriculum in Secondary Schools in Ireland. Education Sciences, 10, 14 https://doi.org/10.3390/educsci10010014

Boylan, M. (2016) Ethical dimensions of mathematics education. Educational Studies in Mathematics Education, 92(3), 395-409. https://doi.org/10.1007/s10649-015-9678-z

Carter, N., Bryant-Lukosius, D., DiCenso, A., Blythe, J., \& Neville, A. J. (2014). The use of triangulation in qualitative research. Oncology nursing forum, 41(5), 545-547. https://doi.org/10.1188/14.ONF.545-547 
Cengiz, C. (2014). The effects of reflective journals kept by pre-service science teachers on reflective thinking and achievement in general chemistry laboratory (Doctoral Dissertation). Karadeniz Technical University, Turkey.

Chiodo, M., \& Bursill-Hall, P. (2019). Teaching Ethics in Mathematics. EMS Newsletter, 12 (114), 38-41.

Coskun, N. (2016). The views of students of faculty of education and faculty members regarding teaching professional ethics values: Hidden curriculum while gaining Professional ethics values [Doctoral Dissertation], Adnan Menderes University.

Creswell, J. W., \& Creswell, J. D. (2017). Research design: Qualitative, quantitative, and mixed methods approaches. Sage publications.

De los Reyes, G., Jr., Kim, T. W., \& Weaver, G. R. (2017). Teaching ethics in business schools:A conversation on disciplinary differences, academic provincialism, and the case for integrated pedagogy. Academy of Management Learning \& Education, 16(2), 314-336. https://doi.org/10.5465/amle.2014.0402

Ehrich, L. C., Kimber, M., Millwater, J., \& Cranston, N. (2011). Ethical dilemmas: a model to understand to teacher practice. Teachers and Teaching: Theory and Practice, 17, 173185. https://doi.org/10.1080/13540602.2011.539794

Ernest, P. (2012). What is our first philosophy in mathematics education? For the Learning of Mathematics, 32(3), $8-14$.

Ernest, P. (2019). The ethical obligations of the mathematics teacher. Journal of Pedagogical Research, 3(1), 80-91. https://doi.org/10.33902/JPR.2019.6.

Gelmez-Burakgazi, S. \& Can, I. (2018). Development and validation of a professional ethics scale for pre-service teachers. International Journal of Curriculum and Instructional Studies, 8(2), 275-298. https://doi.org/10.31704/ijocis.2018.013

Gulcan, N. Y. (2015). Discussing the importance of teaching ethics in education. Procedia Social and Behavioral Sciences, 174, 2622-2625. https://doi.org/10.1016/j.sbspro.2015.01.942

Harfitt, G.J. (2018). The Role of the community in teacher preparation: Exploring a different pathway to becoming a teacher. Frontiers in Education, 3(64), 1-13. http://dx.doi.org/10.3389/feduc.2018.00064

Izadinia, M. (2012). Teacher educators as role models: A qualitative examination of student teachers' and teacher educators' views towards their roles. The Qualitative Report, 17(24), $1-15$.

Karatas, S., Caner, M., Kahyaoglu, R. B., \& Kahya, S. (2019). Perceptions of pre - service teachers on ethical teacher and professional ethics course, Journal of Qualitative Research in Education, 7(1), 29-49. https://doi.org/10.14689/issn.2148-2624.1.7c15.2m

Kumar, G. \& Singh, G. (2010). Professional ethics among teachers. Sahoo, P. K., Yadav, D. and

Das, B. C. (Ed.), Professionalism in Teacher Education: Contemporary Perspectives (1st edition, pp.211220). Concept Publishing.

Lilja, A. (2017). Teachers' experiences of ethics in religious education. In I. O. Franck (Ed.), Assessment in ethics education - A case of national tests in religious education (1st edition, pp. 69-86). Springer.

Lincoln, Y. S., \& Guba, E. G. (1985). Naturalistic inquiry. Sage Publications.

Lumpkin, A. (2008). Teachers as role models: Teaching character and moral virtues. Journal of Physical Education, Recreation and Dance, 79(2), 45-49. https://doi.org/10.1080/07303084.2008.10598134

Lundin, S. (2012). Hating school, loving mathematics: On the ideological function of critique and reform in mathematics education. Educational Studies in Mathematics, 80(1-2), 73-85. https://doi.org/10.1007/s10649-011-9366-6

Lunenberg, M., Korthagen, F. \& Swennen, A. (2007). The teacher educator as a role model. Teaching and Teacher Education, 23, 586-601.

https://doi.org/10.1016/j.tate.2006.11.001

Malone, D. M. (2020). Ethics education in teacher preparation: a case for stakeholder responsibility. Ethics and Education, 15(1), 77-97. 
https://doi.org/10.1080/17449642.2019.1700447

Maloney, T., \& Matthews, J. S. (2020). Teacher Care and Students' Sense of Connectedness in the Urban Mathematics Classroom. Journal for Research in Mathematics Education, 51(4), 399432. https://doi.org/10.5951//resematheduc-2020-0044

Maxwell, B. (2017). Codes of professional conduct and ethics education for future teachers. Philosophical Inquiry in Education, 24(4), 323-347.

Maxwell, B., Tremblay-Laprise, A. A., Filion, M., Boon, H.J, Daly, C., van den Hoven, M. \& Walters, S. (2016). A Five-Country Survey on Ethics Education in Preservice Teaching Programs. Journal of Teacher Education, 67(2), 135-151. https://doi.org/10.1177/0022487115624490.

Mergler, A. (2008) Making the implicit explicit: Values and morals in Queensland teacher education. Australian Journal of Teacher Education, 33(4). http://dx.doi.org/10.14221/aite.2008v33n4.1

Merriam, S.B. (2015). Qualitative research in practice: Introduction to qualitative research. San Francisco: John Wiley and Sons.

Narinasamy, I.,\& Logeswaran, A. K. (2015). Teacher as moral model-Are we caring enough?. World Journal of Education, 5(6), 1-13. https://doi.org/10.5430/wje.v5n6p1

National Association for the Education of Young Children [NAEYC]. (2005). Code of ethical conduct and statement of commitment.

http://www.naeyc.org/files/naeyc/file/positions/PSETH05.pdf

National Association of State Directors of Teacher Education and Certification [NAS-DTEC]. (2015). Model code of ethics for educators. http://www.nasdtec.net/?page=MCEEDoc

National Education Association [NEA]. (2015), Code of ethics. http://www.nea.org/home/30442.htm

Neyland, J. (2004). Toward a postmodern ethics of mathematics education. In M. Walshaw (Eds.), Mathematics education within the postmodern (1st edition, pp. 55-73). Information Age Publishing.

Ordu, A. (2019). Codes of ethics for the teaching profession and teachers' opinions on ethical codes [Master dissertation], Ankara University.

Patton, M. Q. (2014). Qualitative research \& evaluation methods: Integrating theory and practice. Sage publications.

Richardson, V. (1996). The role of attitudes and beliefs in learning to teach. In J. Sikula (Eds.), Handbook of research on teacher education (1st edition pp. 102-119). Association of Teacher Educators.

Roth, W.-M. (2013). Toward a post-constructivist ethics in/of teaching and learning. Pedagogies An International Journal, 8(2), 103-125. https://doi.org/10.1080/1554480X.2013.767769

Sahin-Kiralp, F.S. \& O., Manolova Yalcın. (2017). Unethical behavior and teaching profession: do future teachers have professional ethical principles? Electronic Turkish Studies, 12(18), 591 -604 .

Seghedin, E. (2014). From the teachers professional ethics to the personal Professional responsibility. Acta Didactica Napocensia, (7)4, 13-22.

Simola, S. (2019). Exploring process recording in behavioural ethics education. Journal of Applied Research in Higher Education, 12(3), 534-544. https://doi.org/10.1108/JARHE-072019-0175

Sims, R. R., \& Felton, Jr., E. L. (2005). Successfully teaching ethics for effective learning. College Teaching Methods \& Styles Journal (CTMS), 1(3), 31-48. https://doi.org/10.19030/ctms.v1i3.5237.

Skoe, E.E. (2010). The relationship between empathy-related constructs and care-based moral development in young adulthood. Journal of Moral Education, 39(2), 191-211. https://doi.org/10.1080/03057241003754930

Strike, K. A. \& Soltis, J. F. (2009). The ethics of teaching (5th edition). Teachers College Press.

Tanswell, F.S., Rittberg, C.J. (2020). Epistemic injustice in mathematics education. ZDM Mathematics Education, https://doi.org/10.1007/s11858-020-01174-6. 
Teddlie, C., \& Tashakkori, A. (2003). Major issues and controversies in the use of mixed methods in the social and behavioral sciences. Handbook of mixed methods in social and behavioral research, 1, 13-50.

Timmerman, G. (2009). Teacher educators modelling their teachers?.European Journal of Teacher Education, 32(3), 225-238. https://doi.org/10.1080/02619760902756020

Tirri, K., Toom, A., \& Husu, J. (2013). The Moral Matters of Teaching: A Finnish Perspective. C. J. Craig, P. C. Meijer, J. Broeckmans (Eds.), From Teacher Thinking to Teachers and Teaching: The Evolution of a Research Community (1st edition, pp. 223-240). Emerald Group Publishing.

University Ranking by Academic Performance [URAP] (2019). Overall score table of all universities in Turkey. http://tr.urapcenter.org/2019/2019 t9.php

Warnick, B. R. \& Stemhagen, K (2007) Mathematics teachers as moral educators: the implications of conceiving of mathematics as a technology. Journal of Curriculum Studies, 39(3), 303-316. https://doi.org/10.1080/00220270600977683

Warnick, B. R.,\& Silverman, S. K. (2011). A framework for professional ethics courses in teacher education. Journal of Teacher Education, 62(3), 273-285. https://doi.org/10.1177/0022487110398002

Weil, V. (2005). Standards for evaluating proposals to develop ethics curricula. Science and Engineering Ethics, 11, 501-507. https://doi.org/10.1007/s11948-005-0020-5

Yin, R. K. (2017). Case study research and applications: Design and methods. Sage publications.

\section{Biographical notes:}

Kasım Karataş, completed his bachelor's degree at the Tokat Gaziosmanpaşa University, Department of Counseling and Guidance in 2010; and his master's degree in Curriculum and Instruction at the Ege University in 2013. He obtained a Ph.D. at Dicle University in 2018. He is currently working as a faculty member at Karamanoğlu Mehmetbey University. His areas of interest include culture and learning, ethics and morality in education, culturally responsive teaching, multicultural education.

Nadide YıImaz, completed her bachelor's degree at the Gazi University, Department of Mathematics Education in 2008; and her master's degree in Mathematics Education at the Karadeniz Technical University in 2013. She obtained a Ph.D. at Hacettepe University in 2019. She is currently working as a faculty member at Karamanoğlu Mehmetbey University. Her areas of interest include mathematics education, teacher knowledge, teacher training programmes especially lesson study. 